\title{
Chip-making equipment industry warns of threat from Intel deal
}

[WASHINGTON] A \$250-million research collaboration between Intel and the Department of Energy (DOE) to develop new chip-making technology is coming under fire from US suppliers of semiconductormaking equipment, who fear that it will hand over American technology to their Japanese competitors.

Federico Peña, the energy secretary, who announced the agreement last Thursday, will meet the suppliers in Washington this week and, separately, with staff in the Congress. Many of the staff share the equipment suppliers' concerns about the deal, which is the largest Cooperative Research and Development Agreement (CRADA) ever struck by Department of Energy laboratories.

Under the agreement, a consortium led by Intel will pump $\$ 120$ million in cash into three national laboratories over three years, and provide a further \$130-million worth of support in kind. The money will be spent advancing extreme ultraviolet (EUV) lithography as a technique for etching microcircuits in silicon.

EUV uses radiation of $13.5 \mathrm{~nm}$ wavelength, compared with the visible light wavelengths of $400 \mathrm{~nm}$ or more used in existing photolithography machines, potentially etching far more intricate circuits on to a chip.

"We very much want [the US equipment suppliers] to be able to participate fully in this venture," says Peña. "We're inviting them to Washington to talk. We're trying to be as sensitive to them as possible - and to get the job done."

But Arthur Zafiropoulo, president of Ultratech of San Jose, California, one of the few remaining US makers of lithography equipment, says that the deal will result in Intel handing over an American technology to the Japanese suppliers - Nikon and Canon - that control almost four-fifths of the lucrative worldwide industry. ASML of Holland holds 15 per cent, and small American suppliers just 7 per cent.

"If this proposal is approved, it will have a devastating impact on the fragile lithography equipment industry in the United States," he says. Ultratech and other US equipment suppliers have previously helped to support the EUV work at the laboratories, he points out. "Intel's proposal will subvert this attempt and destroy the US lithography industry," he says.

The laboratories' expertise in EUV arose in part from the Strategic Defense Initiative, which developed precision optics to manipulate ultraviolet radiation, and partly from nuclear weapons research. In all, 90 per cent of the deal would be shared by two weapons laboratories, Lawrence Livermore National Laboratory in California and the Sandia National Laboratory in New Mexico. The rest goes to the Ernest Lawrence Berkeley National Laboratory in California, where the Advanced Light Source would aid the project.

Intel has sought partners in the microchip industry for the consortium, called EUV Limited Liability Company, which will run the collaboration. But the two other major participants in lithography research,

\section{Brussels slims down advisory body}

[MUNICH] The European Commission in Brussels last week approved its restructured science advisory group, the European Science and Technology Assembly (ESTA). The new assembly, whose numbers have been cut from 100 to around 60 , with a higher proportion of academic representation than before, will take up its responsibilities next month when the term of the current assembly expires.

ESTA was set up as an advisory group to the commission three years ago, with members primarily from academic institutions and industry. Its reports have included the role of basic research in Europe and the future of nuclear fusion research (see Nature 387, 328; 1997).

But the assembly also had teething problems. Lack of administrative support from the commission led last year to the threatened resignation of its chairman, Jan Borgman, former head of the Dutch National Research Council (see Nature 381, $180 ; 1996)$. A permanent secretariat has now been established within the commission.

As the number of representatives was found unwieldy, the assembly has been trimmed by a third, and ESTA's 'bureau', the executive group which has 20 members, will be trimmed similarly.

The new assembly will meet for the first time at the beginning of October, when it will elect a chairman who will be ultimately responsible for choosing topics for its future reports. The chairman will also have to consider how to take forward ESTA's most recent report, which sought to identify strengths and weaknesses in Europe's basic research, but was criticized for lack of internal consistency.

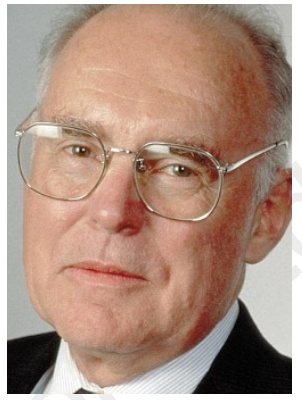

Intel's Moore: backing ultraviolet lithography.
IBM and Lucent Technologies, have not joined. Advanced Micro Devices (AMD) and Motorola, the two partners who have done so, are said by one source to be investing less than $\$ 1$ million each.

Department of Energy laboratories are allowed to do proprietary research for individual companies as well as for consortia, but Congressional staff are nonetheless concerned about several aspects of the EUV CRADA. These include whether Intel will pay the full overhead costs of scientists engaged on the project; the national security implications of releasing the technology, possible future foreign involvement in the consortium, and the intellectual property rights of companies originally involved in the technology.

"It is more than just the concern of a few companies," one staff member says. "We want to know what procedures the DOE has in place to vet an agreement of this size."

As Zafiropoulo points out, the competitiveness implications of the deal are easily large enough to attract Congressional attention. "This is a significant trade issue. We are talking about a $\$ 25$-billion market" in the early years of the next century, he says.

IBM researchers continue to back conventional x-ray lithography (with a wavelength of $1 \mathrm{~nm}$ ) as the successor to light-based techniques, while Lucent is pursuing techniques that use electron beams. "The winner certainly isn't obvious at this time, but we think that EUV is a very strong alternative," says Gordon Moore, the founder of Intel and coiner of "Moore's law", which states that the density of transistors on microchips should double every two years.

The obstacles facing the deal are significant, say congressional staff. But the booming US economy means that continuing Japanese dominance in one key industry semiconductor manufacturing equipment - is a less potent threat than it would have seemed a decade ago.

The DOE will argue that the deal, which effectively contracts out to the private sector research work that was losing support from the government, closely reflects what Congress has said it wants the laboratories to do.

Colin Macilwain 